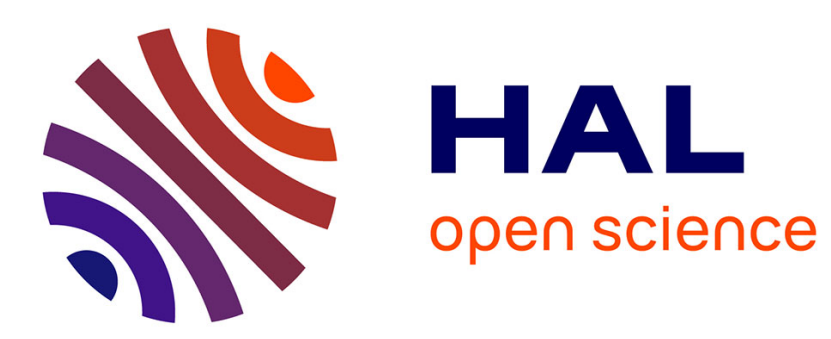

\title{
Advances and Prospects in Wheat Eyespot Research: Contributions from Genetics and Molecular Tools
}

\author{
Le Wei, Helene Muranty, Huaigang Zhang
}

\section{To cite this version:}

Le Wei, Helene Muranty, Huaigang Zhang. Advances and Prospects in Wheat Eyespot Research: Contributions from Genetics and Molecular Tools. Journal of Phytopathology, 2011, 159 (7-8), pp.457470. 10.1111/j.1439-0434.2011.01795.x . hal-02647460

\section{HAL Id: hal-02647460 \\ https://hal.inrae.fr/hal-02647460}

Submitted on 29 May 2020

HAL is a multi-disciplinary open access archive for the deposit and dissemination of scientific research documents, whether they are published or not. The documents may come from teaching and research institutions in France or abroad, or from public or private research centers.
L'archive ouverte pluridisciplinaire HAL, est destinée au dépôt et à la diffusion de documents scientifiques de niveau recherche, publiés ou non, émanant des établissements d'enseignement et de recherche français ou étrangers, des laboratoires publics ou privés. 
Version définitive du manuscrit publié dans / Final version of the manuscript published in :

Journal of Phytopathology, 2011, 159 (7-8), 457-470

http://dx.doi.org/10.1111/j.1439-0434.2011.01795.x

\title{
Review Article
}

The final version of this article can be found at doi: 10.1111/j.1439-0434.2011.01795.x

\section{Advances and Prospects in Wheat Eyespot Research: Contributions from Genetics and Molecular Tools

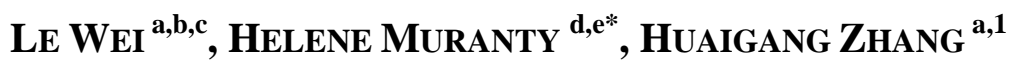

\begin{abstract}
( ${ }^{a}$ Northwest Institute of Plateau Biology, Chinese Academy of Sciences, Xining, Qinghai 810001, China; ${ }^{\mathrm{b}}$ Graduate University, Chinese Academy of Sciences, Beijing 100049, China; ${ }^{\mathrm{c}}$ College of Biologic and Geographic Sciences, Qinghai Normal University, Xining, Qinghai 810008, China; ${ }^{\mathrm{d}}$ INRA-AgroCampus Ouest UMR 118 Amelioration des Plantes et Biotechnologies Vegetales, BP 35327, 35653 Le Rheu CEDEX, France; ' present address INRA UR 588 Amelioration Genetique et Physiologie Forestiere, 2163 Avenue de la Pomme de Pin, CS40001 Ardon, 45075 Orleans
\end{abstract}

CEDEX 2)

Key words: disease resistance; Triticum aestivum; Oculimacula spp. genetics; gene tagging

\begin{abstract}
Eyespot disease caused by the soil-borne facultative fungi Oculimacula yallundae and $O$. acuformis is the major component of the stem-base disease complex of wheat in temperate regions of the world with a cool and wet climate. In this review, we focus on results of genetic studies concerning both partners of the host-pathogen interaction. This comprises analyses of genetic diversity of the pathogen and identification of particular genes within it, evaluation and screening methods for host resistance, resistance sources and genetics of these resistances, breeding of resistant cultivars in wheat, and application of genetic markers in tagging and tracking of eyespot resistance genes. We also attempt to foresee some of the key issues and developments that may occur in future. The identification of markers tightly linked to eyespot resistance genes is the important research focus opening the door to marker-assisted selection of resistant varieties.
\end{abstract}

\section{Introduction}

Wheat production is limited by various abiotic and biotic factors. It is influenced by a number of diseases, mainly of pathogenic fungal origin. These can reduce kernel yield and quality and cause

\footnotetext{
${ }^{1}$ Corresponding author: Huaigang Zhang Tel: 86-0971-6163352 E-mail address: hgzhang@ @wipb.ac.cn

Helene Muranty Tel: 33 (0)2 38417847 - E-mail address: Helene.Muranty@ orleans.inra.fr
} 457-470. DOI : 10.1111/j.1439-0434.2011.01795.x 


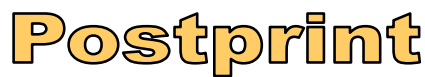

Version définitive du manuscrit publié dans / Final version of the manuscript published in :

Journal of Phytopathology, 2011, 159 (7-8), 457-470 http://dx.doi.org/10.1111/j.1439-0434.2011.01795.x dramatic yield losses (King 1977; Fitt and Goulds 1988; Griffey et al. 1994; Marshall and Sutton 1995). Eyespot, caused by the soil-borne facultative fungi Oculimacula yallundae (Wallwork \& Spooner) Crous \& W. Gams [formerly Tapesia yallundae, anamorph Helgardia (formerly Pseudocercosporella) herpotrichoides] and O. acuformis (Boerema, R. Pieters \& Hamer) Crous \& W. Gams [formerly Tapesia acuformis, anamorph Helgardia (Pseudocercosporella) acuformis], is a component of the stem-base disease complex of wheat (Lucas et al. 2000; Crous et al. 2003). Eyespot forms lesions on the leaf sheaths and culms near the soil level and their elliptical shape gives rise to the name of the disease which is also known as strawbreaker or foot rot. Eyespot pathogens have a wide host range among cereals and grass species (Lucas et al. 2000). Wheat, barley, rye, oats, and other related grasses can be affected, with wheat being the most susceptible (Murray et al. 1994; Chapman et al. 2008). Sexual reproduction of O. yallundae can occur on some wild grasses [e.g., Bromus diandrus, Hordeum leporinum (Wallwork 1987) or Holcus lanatus (Dyer and Bradshaw 2002)], which may provide a reservoir of primary inoculum to infect cultivated fields. Significant damages due to eyespot are observed on winter wheat and fall-sown spring wheat in temperate regions of the world with cool and wet climates where fall-sown cereals predominate (Lucas et al. 2000). Measures to control eyespot include cultural practices (sowing date and density, tillage practice, crop rotation), chemicals (fungicides) and biological control. The development of wheat cultivars with genetic resistance is recognized as the most effective, economic, environmental-friendly and sustainable strategy to control the disease. Previous reviews mainly concerned epidemiology and management of eyespot (Fitt and Goulds 1988; Fitt et al. 1990) or the biology and genetics of Oculimacula species (Lucas et al. 2000). Furthermore, eyespot was one of the examples in reviews concerning sensory biology of wheat pathogens (Lucas 2004), molecular mechanisms of fungicide resistance (Ma and Michailides 2005) or coexistence of sister pathogen species in arable crops (Fitt et al. 2006). The current review focuses on molecular genetic studies on the pathogen on one hand, and on resistance to eyespot in host plants and practical implications for wheat breeders on the other.

\section{Molecular genetic studies of the pathogens}

As mentioned by Lucas et al. (2000) molecular genetic studies of eyespot pathogens are practicable: they can be cultivated on artifical media, they can be transformed (Blakemore et al. 1989) to study complementation, to insert reporter genes (Bunkers 1991; Bowyer et al. 2000; Eckert et al. 2005) or to obtain mutants, and techniques allowing in vitro sexual crosses between compatible strains were developed (Dyer et al. 1993). However, few genes of Oculimacula sp. have been identified so far, with only 27 sequences in the NCBI nucleotide database, and nine in the protein database (15 July 2010). 


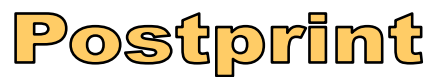

Version définitive du manuscrit publié dans / Final version of the manuscript published in :

Journal of Phytopathology, 2011, 159 (7-8), 457-470 $\quad$ http://dx.doi.org/10.1111/j.1439-0434.2011.01795.x

During the 1990s, several genetic marker systems were used to study genetic diversity in eyespot pathogens. These were isozymes (Julian and Lucas 1990; Priestley et al. 1992), restriction fragment length polymorphisms (RFLP) and other DNA-hybridization based marker systems (Nicholson et al. 1991; Thomas et al. 1992; Frei and Wenzel 1993; Nicholson et al. 1993; Poupard et al. 1995; Takeuchi and Kuninaga 1996), random amplified polymorphic DNAs [RAPDs, (Nicholson and Rezanoor 1994; Nicholson et al. 1994; Papaikonomou and Lucas 1994; Vanova et al. 2000)]. These studies mainly targeted identification of molecular fragments enabling discrimination of the two Oculimacula species. They also showed that $O$. yallundae had a higher degree of polymorphism than O. acuformis. The competitive PCR assay developed by Nicholson et al. (1997) on the basis of specific RAPD fragments was later used in several studies that evaluated the effects of various factors, e.g. fungicide treatments, cultivars with different eyespot susceptibilities, soil management, farming practices, or the preceding crop, on the incidence and severity of stem-base diseases of wheat (Bateman et al. 2000; Turner et al. 2001; Nicholson et al. 2002; Matusinsky et al. 2008a, b, 2009).

The rDNA genes were used to design PCR-based tests to rapidly differentiate the two types of Oculimacula isolates (Poupard et al. 1993; Gac et al. 1996) that were not definitively known as separate species at that time. These tests were used to study the development of $O$. yallundae and $O$ acuformis in the field and to evaluate the effect of a fungicide seed treatment (Gac et al. 1999). Ray et al. (2004) used competitive PCR assays designed on rDNA genes that enabled quantification of $O$. yallundae, O. acuformis and other pathogens involved in stem-base diseases of wheat to study the effectiveness of various fungicide treatments on disease index and yield. Similar assays were also used to evaluate the effects of eyespot on stem strength, lodging resistance and yield (Ray et al. 2006). The rDNA genes of four isolates were sequenced by Stewart et al. (1999) and these results lead Crous et al. (2003) to define the specific genus name Oculimacula for the fungi associated with eyespot in cereals. These sequences were used to design a real-time PCR assay to discriminate $O$. yallundae and $O$. acuformis from other fungal species found on wheat and to quantify the pathogens in wheat plants (Walsh et al. 2005). The rDNA sequence of Helgardia anguioides obtained by Stewart et al. (1999) enabled the identification of this fungus within the wheat root microbial community (Kwasna et al. 2010).

The two mating type alleles of Oculimacula yallundae were isolated by Singh et al. (1999). With these data, Dyer et al. (2001) designed a multiplex PCR test for determining mating type in both $O$. yallundae and $O$. acuformis. Douhan et al. (2002a) used this test to analyse Oculimacula populations found in the U.S. Pacific Northwest. These results and a complementary AFLP analysis indicated that both species were represented by random mating populations undergoing partial asexual reproduction at the scale studied (Douhan et al. 2002b, 2003). 


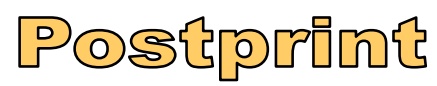

Version définitive du manuscrit publié dans / Final version of the manuscript published in :

Journal of Phytopathology, 2011, 159 (7-8), 457-470 http://dx.doi.org/10.1111/j.1439-0434.2011.01795.x

The ornithine decarboxylase (ODC) gene was studied by Mueller et al. (2001) as a candidate gene involved in polyamine metabolism, and that could be critical during cell proliferation observed in the first steps of the infection process. The ODC knockout mutants obtained in this study were unable to differentiate infection plaques in vitro, but were not reduced in virulence towards wheat when compared to a normal strain. Consequently, the ODC gene was considered not to be a suitable target for fungicides.

Two genes involved in fungicide resistance were also studied. Mutations in the $\beta$-tubulin gene were associated with different phenotypes of benzimidazole resistance (Albertini et al. 1999), whereas contradictory results were obtained concerning the association of mutations in the $14 \alpha$-demethylase gene (CYP51) with resistance to DMI (sterol 14 $\alpha$-demethylase inhibitor) fungicides like prochloraz (Wood et al. 2001; Albertini et al. 2003). Genetic analyses in sexual crosses between isolates of $O$. yallundae with varying levels of prochloraz resistance indicated that resistance is controlled by a major gene and several minor genes (Dyer et al. 2000).

\section{Methods for the assessment of eyespot resistance}

Various techniques for evaluating eyespot resistance in wheat genotypes have been used by breeders. It was early realized that controlled inoculations with the pathogen would give a more reliable assessment of eyespot resistance than natural infection because artificial inoculation is more uniform than the natural one. Techniques were described for the production of inoculum and for inoculation in the field (Bruehl and Nelson 1964) or in growth chambers (Macer 1966). The advantage of the growth chamber test was that it was more rapid (2-3 months) than a field test, which requires a quite complete growing season. The growth chamber test measures mainly resistance to penetration of the leaf sheaths, whereas the field test measures mainly resistance of the stem to invasion by the fungus. Because the two kind of resistance are not completely correlated it should be better to measure both (Doussinault 1973). In both tests, ratings are based on an index: several plants (10-20 in growth chamber tests and approximately 50 tillers in field tests) are scored for number of penetrated leaf sheaths (growth chamber tests) or the portion of the stem attacked by the fungus (field tests), and their scores are averaged to obtain the index. With such index techniques, resistance evaluations are time-consuming and labour-intensive (Johnson 1992b). They are also difficult to apply to heterogeneous material such as segregating families in early generations after crossing. For heterogeneous populations, it was preferred to select for yield or seed size in a naturally infested environment or in inoculated trials (Doussinault 1973; Roberts and Allan 1990). However, it soon appeared that if the population was also heterogeneous for plant height or earliness, this procedure tended to select tall and vigorous plants and that the selection pressure on eyespot resistance was not sufficient. Consequently, it was proposed that selection for 


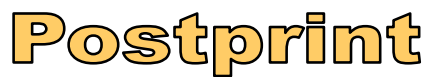

Version définitive du manuscrit publié dans / Final version of the manuscript published in :

Journal of Phytopathology, 2011, 159 (7-8), 457-470 http://dx.doi.org/10.1111/j.1439-0434.2011.01795.x

yield in inoculated trials should be delayed until attainment of near-homozygosity by single-seed descent (Roberts and Allan 1990) or should be applied after classifying plants on height (Doussinault 1973).

Several variations of the growth chamber test were proposed to reduce its duration. For example, Murray and Ye (1986) observed that papillae formation, hypersensitive reaction at papillae sites and number of successful penetrations were correlated with host resistance, and Strausbaugh and Murray (1989) used the percentage of successful penetrations in the first leaf sheath at 50 infection sites to study the inheritance of eyespot resistance in segregating $\mathrm{F}_{2}$ and backcross populations. This method allowed assessment 4 weeks after inoculation, but remained time-consuming and quite subjective.

An improved method using a $\beta$-glucuronidase (GUS)-transformed strain of the pathogen was developed to measure differences in disease development on 4- to 8-week-old wheat seedlings (de la Peña and Murray 1994). This method differentiated highly resistant, resistant, and susceptible genotypes (Jones et al. 1995). After inoculation with the GUS-transformed strain, production of the GUS-enzyme is highly correlated with the amount of fungal growth in the plant. Thus disease severity or differences in resistance to eyespot are directly related to the amount or differences in GUS activity in seedling tissues of wheat genotypes. The results of this seedling test are highly correlated with visual ratings made on 6- to 8-week-old young plants and were considered to be sufficient to predict adult-plant resistance under Pacific Northwest conditions. Using this method, evaluation of resistance could be reduced from about 11 months to 2 months (Jones et al. 1995). The GUS seedling test has been used to identify new sources of eyespot resistance in wild relatives of wheat, to determine the genetic control of resistance, and to facilitate mapping and tagging of eyespot resistance genes (Murray et al. 1994; Yildirim et al. 1995, 1998; de la Peña et al. 1996, 1997; Cadle et al. 1997; Figliuolo et al. 1998; Lucas et al. 2000; Li et al. 2004, 2005). With only one GUS-transformed strain used for resistance testing there was a risk of selecting specific resistance genes conferring resistance to only a limited portion of the pathogen populations. That is probably why Li et al. (2004) used a mixture of four GUS-transformed strains in their study.

Lind (1992) developed a method based on an enzyme-linked immunosorbent assay (ELISA) to measure quantitative differences in eyespot resistance among wheat cultivars. This method detected the fungus in presymptomatic wheat plants and could be applied at different growth stages, but only measurements taken at or after anthesis correlated well with response at the adult stage (Lind 1992), whereas measurements taken at younger growth stages, particularly around tillering, were not able to discriminate resistant from highly resistant genotypes (de la Peña and Murray 1994). The method was applied to study the stability of eyespot response measured by ELISA in 20 wheat cultivars studied in six environments (Lind et al. 1994), relative rates of $O$. yallundae and $O$. acuformis 


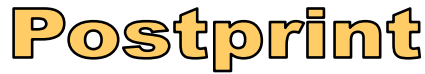

Version définitive du manuscrit publié dans / Final version of the manuscript published in :

Journal of Phytopathology, 2011, 159 (7-8), 457-470 $\quad$ http://dx.doi.org/10.1111/j.1439-0434.2011.01795.x development in wheat (Poupard et al. 1994), variation in eyespot response in Pchl-carrying genotypes (Lind 1999), and quantitative inheritance of eyespot resistance in diallel crosses (Lind 2000).

The competitive PCR assay developed by Nicholson et al. (1997) was rarely used by wheat breeders or geneticists, probably for cost reasons and because it is time-consuming. Uslu et al. (1998) observed that Oculimacula DNA quantification by competitive PCR did not correlate well with visual ratings and was not powerful in revealing small differences between genotypes, probably because the method evaluates the level of colonization rather than penetration and had to be applied on bulks of individual plants that had different visual disease scores. More recently, real-time PCR was demonstrated to be useful in discriminating and quantifying $O$. yallundae and $O$. acuformis in plants (Walsh et al. 2005). In the context of wheat genotype evaluation, assays based on this technique were developed by Meyer et al. (2006; 2008) and by Gedye and Murray [unpublished work cited by Li et al. (2008)].

None of these tests is simple and highly effective; all still need inoculation with pathogens and replicated testing is necessary owing to environmental variation and genotype by environment interaction.

\section{Sources of eyespot resistance and resistance genes found in relative species of wheat}

There are several known sources of resistance to eyespot, but only three resistance genes have been described. The French cultivar 'Cappelle-Desprez' reported by Vincent (1952) was the first commercial wheat cultivar resistant to eyespot. Most of its resistance is conferred by Pch2 which is located at the distal end of the long arm of chromosome 7A and acts at the seedling or young plant stage (Law et al. 1975; Koebner and Martin 1990; de la Peña et al. 1996, 1997; Chapman et al. 2008). Other genes on chromosomes 1A, 2B and 5D of 'Cappelle-Desprez' modify the levels of infection at the young plant stage (Law et al. 1975). Pch2 can also be analyzed as a quantitative trait when its effect does not permit plants to be clearly classified into resistant and susceptible types (Hollins et al. 1988; Chapman et al. 2008). Recently, Pch2 was found to confer a significantly less effective resistance against $O$. yallundae than $O$. acuformis at the young plant stage (Burt et al. 2010). In another study, chromosomes 5A, 1A and 2B were shown to carry genes for resistance against $O$. yallundae at the adult stage whereas Pch2 did not have an effect (Muranty et al. 2002). Although the pedigree of 'Cappelle-Desprez' is known, the origin of Pch2 and other eyespot resistance genes in 'Cappelle-Desprez' is not known (Murray et al. 1994). The origin of Pch2 could be in an A-genome species like T. monococcum, as suggested by Cadle et al. (1997). 'Cappelle-Desprez' was selected in an environment with a long history of exposure to the disease where selection for resistance was probably done without much effort (Law et al. 1975). In the UK 


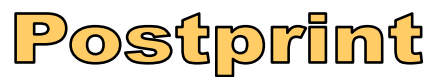

Version définitive du manuscrit publié dans / Final version of the manuscript published in :

Journal of Phytopathology, 2011, 159 (7-8), 457-470 $\quad$ http://dx.doi.org/10.1111/j.1439-0434.2011.01795.x during the 1960s and 1970s selection for the resistance carried by 'Cappelle-Desprez' was usually achieved by breeding within a pool of varieties derived from 'Cappelle-Desprez' and thought to be homozygous for resistance (Law et al. 1988).

A few other wheat cultivars were reported to show moderate resistance to eyespot apparently not inherited from 'Cappelle-Desprez'. These are for example 'Kanzler', 'Florida' and 'Kraka' from Germany (Lind et al. 1994), 'Cerco' (Peterson et al. 1974), and 'Edwin' (Jones et al. 2000) developed in the Pacific Northwest. The genetic control of eyespot resistance in these cultivars has not been studied.

Some cultivars are also sometimes rated moderately resistant and sometimes susceptible: for example, 'Stephens' (Kronstad et al. 1978) and 'Viking' [mentioned as moderately resistant by Murray and Ye (1986) and Murray and Bruehl (1986) and as susceptible by Strausbaugh and Murray (1989) and Murray and Bruehl (1983)]. This illustrates the high genotype x environment interaction that confuses phenotypic test results, or possibly unreliability of the assays.

The most effective resistance is due to the single major gene Pchl, which was transferred to wheat from Aegilops ventricosa in three independent programs. Pchl was transferred to hexaploid wheat by first crossing Ae. ventricosa $\left(2 \mathrm{n}=4 \mathrm{x}=28\right.$, genome $\left.\mathrm{D}^{\mathrm{V}} \mathrm{D}^{\mathrm{V}} \mathrm{M}^{\mathrm{V}} \mathrm{M}^{\mathrm{V}}\right)$ with an accession of the tetraploid species Triticum persicum $(2 \mathrm{n}=4 \mathrm{x}=28$, genome AABB) to obtain a fertile amphidiploid and subsequently backcrossing with the hexaploid wheat $(2 \mathrm{n}=6 \mathrm{x}=42$, genomes AABBDD) variety 'Marne-Desprez' for three generations to develop Ventricosa x Persicum x Marne (=VPM-1) (Simonet 1957; Maia 1967). Pchl was transferred to the distal part of chromosome arm 7DL of wheat via recombination between the $7 \mathrm{D}^{\mathrm{v}}$ chromosome of Ae. ventricosa and the $7 \mathrm{D}$ chromosome of a susceptible wheat (Gale et al. 1984; Chao et al. 1989). VPM-1 became a ready source of the eyespot resistance gene Pchl for wheat breeders. Genetic material from Ae.ventricosa was also transferred to hexaploid wheat via an intermediate male-sterile hybrid between $T$. turgidum $(2 \mathrm{n}=4 \mathrm{x}$ $=28$, genomes $\mathrm{AABB}$ ) and Ae. ventricosa that was backcrossed as female parent with hexaploid wheat. The progeny were then repeatedly selfed to obtain stable wheat lines with 42 chromosomes, designated H-93 lines (Doussinault et al. 1983a). The resistance factor in line H-93-70 was confirmed to be allelic to the Pchl gene of VPM-1 and to be transferred from chromosome $7 \mathrm{D}^{\mathrm{V}}$ of Ae. ventricosa to chromosome 7D (Delibes et al. 1988; Worland et al. 1988; Mena et al. 1992). In the third program, eyespot resistance from Ae. ventricosa was transferred to bread wheat by a direct cross. A hybrid between T. aestivum 'Moisson' and Ae. ventricosa was open-pollinated with an unidentified T. aestivum plant, and a resulting hybrid was backcrossed to T. aestivum 'Courtot', followed by a further cross to T. aestivum 'Moisson'. The resulting plants were selfed to establish pure lines (Doussinault et al. 1988). These lines, known as F-210, were shown to have a very high resistance level (Lind 1999). 


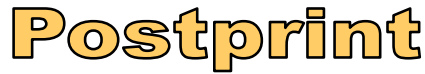

Version définitive du manuscrit publié dans / Final version of the manuscript published in :

Journal of Phytopathology, 2011, 159 (7-8), 457-470 $\quad$ http://dx.doi.org/10.1111/j.1439-0434.2011.01795.x

Eyespot resistant accessions were identified with a GUS-transformed strain of $O$. yallundae in Triticum tauschii (Yildirim et al. 1995), T. monococcum (Cadle et al. 1997), T. durum, T. dicoccoides and T. turanicum (Figliuolo et al. 1998), Dasypyrum villosum (Yildirim et al. 2000), Thinopyrum ponticum and Th. intermedium ( $\mathrm{Li}$ et al. 2004; Li et al. 2005) and Aegilops longissima (Sheng and Murray 2009). Immune and highly resistant accessions were also identified in $T$. tauschii with a non-transformed strain (Assefa and Fehrmann 1998). Hundreds of accessions of $T$. tauschii were screened and shown to carry a high frequency of resistance (Jones et al. 1995; Yildirim et al. 1995). Crosses between resistant and susceptible T. tauschii accessions indicated that a single gene controlled eyespot resistance in each cross, and tests with molecular markers showed that this gene is probably not allelic to Pchl (Cadle et al. 1998), but the chromosome location of a resistance gene in T. tauschii is still unknown. Sheng and Murray (2009) identified eyespot resistant Ae. longissima accessions and initiated genetic analyses of eyespot resistance with molecular markers in crosses between resistant and susceptible accessions. Among 22 T. monococcum accessions, a dozen were shown to have an intermediate to high level of eyespot resistance, and four of these had significantly different responses to O. yallundae and O. acuformis (Burt et al. 2010).

A part of the Gatersleben genetic resource collection was tested for eyespot resistance, mainly under natural disease pressure but also with artificial inoculations (Boerner et al. 2006). A quite high number of accessions of the Triticum genus (46 at the seedling stage, 412 at the adult stage) were scored with no visible infection under natural infection, and, more than half the Aegilops accessions had no visible infection under natural infection. These putatively highly eyespot resistant accessions deserve further investigation using artificial inoculations.

High levels of resistance reported by Sprague (1936) in Dasypyrum villosum (L.) Candargy ( $2 \mathrm{n}=$ 14, genome VV), a distant relative of wheat, were confirmed by Murray et al. (1994) who also showed that a chromosome $4 \mathrm{~V}$ addition line in a 'Chinese Spring' background was as resistant as VPM-1. In a cross between the susceptible 'Yangmai-5' (4V(4D)) substitution line and the resistant $4 \mathrm{~V}$ disomic addition line, the resistance gene PchDv (Pch3) from D. villosum was located on the distal part of the long arm of chromosome 4V (Yildirim et al. 1998). Although five tested accessions of $D$. villosum were resistant to both $O$. yallundae and $O$. acuformis, analysis of single chromosome addition lines in a 'Chinese Spring' background showed that resistance to the two eyespot pathogens may be conferred by different genes (Uslu et al. 1998).

The wheatgrasses Th. ponticum and Th. intermedium were reported as potential sources of resistance to eyespot that could be used in perennial wheat ( = Triticum spp. X Th. ponticum or Th. elongatum) breeding (Cox et al. 2002), whereas an eyespot tolerant germplasm line with Th. ponticum in its pedigree was registred by Allan et al. (1993). Genetic analyses of a chromosome substitution line in which chromosome 4D was replaced by chromosome 4J of Th. ponticum 


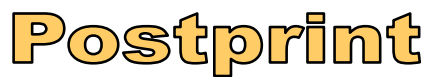

Version définitive du manuscrit publié dans / Final version of the manuscript published in :

Journal of Phytopathology, 2011, 159 (7-8), 457-470 $\quad$ http://dx.doi.org/10.1111/j.1439-0434.2011.01795.x indicated that eyespot resistance in offspring of this line was associated with the $4 \mathrm{~J}$ chromosome (Li et al. 2004). A related study with chromosome substitution or translocation lines incorporating $T h$. intermedium chromosomes or chromosome arms indicated that eyespot resistance is associated with the short arm of chromosome $4 \mathrm{Ai} \# 2\left(=4 \mathrm{~J}^{\mathrm{S}}\right)(\mathrm{Li}$ et al. 2005). These resistance sources require further chromosomal engineering to remove deleterious factors introduced with the alien chromatin (Li et al. 2008).

Aegilops kotschyi $\left(2 \mathrm{n}=28\right.$, genome $\left.\mathrm{UUS}^{\mathrm{v}} \mathrm{S}^{\mathrm{v}}\right)$ was described as a further source of resistance to eyespot pathogens [Bang (1986), cited in Lind (2000)] and was used to develop introgression lines in a wheat background by crossing and twice backcrossing to three German wheat varieties, followed by selfing for line development (Thiele et al. 2002). Among these lines, several were as resistant as 'Cappelle-Desprez' but none were as resistant as Pchl-carrying controls. The genetic basis of this resistance was studied by Meyer et al. (2008) in a doubled haploid population, and it seemed to be of more minor effect than previously thought and due to several minor genes.

\section{Development of eyespot resistant cultivars}

Variable emphasis has been placed on eyespot resistance in different breeding programs around the world during the last 60 years. When fungicides were not used, selection of wheat in Western Europe occurred in environments largely attacked by the disease and selection for resistance went along with selection for yield (Law et al. 1975). When breeders began to use fungicides in yield trials, nowadays current practice, they had to perform separate tests to select for eyespot resistance.

The cultivar 'Cappelle-Desprez' and the gene Pchl from the breeding line 'VPM-1' are the most widely used sources of resistance to eyespot. Examples of cultivars that are thought to have inherited 'Cappelle-Desprez' resistance are 'Hobbit sib' (Worland et al. 1988) 'Avalon', 'Longbow', 'Norman', 'Virtue' (Hollins et al. 1988), 'Maris Huntsman' (Johnson 1992b), 'Apollo', 'Sperber', 'Boxer', 'Sorbas', 'Rektor' (Lind et al. 1994), 'Joss', 'Maris Beacon', 'Xanthos', and 'Adular' (Lind 2000). The presence of Pch2 was confirmed or inferred from molecular genotyping results in 'Hobbit sib', 'Lynx', 'Rendezvous' and 'Riband' (Burt et al. 2010).

Of the three described resistance genes, Pchl is the most extensively used in development of eyespot resistant wheat cultivars due to its tight linkage with an isozyme marker (McMillin et al. 1986). However, as early as the 1970s, Doussinault et al. (1974) started to breed new wheat lines with a VPM parent, selecting for eyespot resistance at the young plant and adult stages and for other agronomic traits like earliness, height, yield and quality. These efforts led to the registration of the French cultivar 'Roazon' which was the first commercial wheat to contain the eyespot resistance gene Pchl of VPM-1. The two other sources where Pch1 was introduced, i.e. the H93 lines (Delibes and Garcia-Olmedo 1973; Mena et al. 1992) and the F-210 lines (Doussinault et al. 1988; Lind 


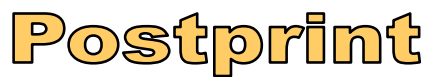

Version définitive du manuscrit publié dans / Final version of the manuscript published in :

Journal of Phytopathology, 2011, 159 (7-8), 457-470 $\quad$ http://dx.doi.org/10.1111/j.1439-0434.2011.01795.x 1999), have not been reported as sources of eyespot resistance in wheat cultivars. This is perhaps due to the fact that the A. ventricosa accession used to develop this lines was different from the accession used to obtain VPM, and the associated allele at the linked isozyme locus is a null allele in these sources (Huguet-Robert et al. (2001); J. Jahier, personal communication). The French cultivar 'Roazon' was never widely grown (Jones et al. 1995).

The USDA-ARS winter wheat breeding program at Washington State University started to work with Pchl carrying lines in 1974. The first lines combining high yield potential, adequate cold-hardiness, good milling-quality and eyespot resistance conferred by Pchl were released as 'Madsen' (Allan et al. 1989) and 'Hyak' (Allan et al. 1990) and were derived from VPM/Moisson selections. Further varieties with Pchl were developed for the Pacific Northwest and several other regions around the world (Table 1).

\section{Genetic markers of eyespot resistance genes}

It has long been recognized that markers that could be use to indirectly select resistant individuals and manipulate eyespot resistance genes would greatly facilitate breeding. Several markers linked with the three described eyespot resistant genes (Pch1, Pch2, Pch3) have been published and these results are summarized in Table 2.

The endopeptidase allele Ep-DIb derived from the long arm of chromosome $7 \mathrm{D}^{\mathrm{V}}$ of $A e$. ventricosa like $P \operatorname{chl}$ provides a particularly efficient marker for the presence of $P \operatorname{chl}$, and is widely used for classification and selection of resistant breeding lines (McMillin et al. 1986; Vahl et al. 1987; Koebner et al. 1988; Law et al. 1988; Summers et al. 1988; Worland et al. 1988; Vahl and Müller 1991; Mena et al. 1992; Santra et al. 2006). The other tightly linked markers are a RFLP marker Xpsr121 (Chao et al. 1989), whose probe was found to encode a beta-glucanase, the dominant simple sequence repeat (SSR) markers Xbarc97, Xwmc14 and Xcfd175, failing to amplify an Ae.ventricosa allele, which are suitable only for screening homozygous materials and cannot detect failed reactions (Chapman et al. 2008), a dominant sequence tagged site (STS) marker $X B$-glu7D derived from a 7D beta-glucanase expressed sequence tag (EST) (Chapman et al. 2008), and three STS markers Xorw1, Xorw5 and Xorw6 (Leonard et al. 2008).

Several markers loosely linked to Pch2 were identified in the 1990s: these were an isozyme marker Ep-A1 (Koebner and Martin 1990) and the RFLP markers Xpsr121 (de la Peña et al. 1996), Xcdo347 and Xwg380 (de la Peña et al. 1997). More recently, the first association of Pch2 with PCR-based markers was reported (Chapman et al. 2008). In this study, Pch2 was shown to be associated with three SSR markers and to map close to Xwmc525 within a $7 \mathrm{cM}$ interval flanked by Xwmc346 and Xcfa2040 (Chapman et al. 2008). Markers for Pch2 were also developed from cDNA-AFLP fragments differentially expressed between 'Chinese Spring' and 'Chinese Spring 457-470. DOI : 10.1111/j.1439-0434.2011.01795.x 


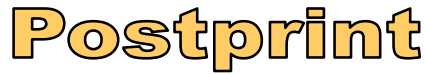

Version définitive du manuscrit publié dans / Final version of the manuscript published in :

Journal of Phytopathology, 2011, 159 (7-8), 457-470 $\quad$ http://dx.doi.org/10.1111/j.1439-0434.2011.01795.x (Cappelle-Desprez 7A)': two markers, X4CD7A8 and X33CD7A8, were mapped in the same terminal deletion bin of chromosome arm 7AL (7AL15-0.99-1.00) as Xcfa2040, but could not be mapped in the 'Chinese Spring (Cappelle-Desprez 7A)' x 'Chinese Spring' population due to a lack of polymorphism (Chapman et al. 2009). Finally, 5 AFLP markers were significantly associated with eyespot resistance in a DH population segregating for Pch2 (Meyer et al. 2008).

Restriction fragment length polymorphisms markers Xcdo949 and Xbcd588 bracket the gene Pch3 on chromosome 4V in a wheat background in a 33-cM interval and simultaneous selection for both flanking markers would theoretically select $96.7 \%$ of the genotypes having Pch3 (Yildirim et al. 1998).

\section{Durability of eyespot resistance genes}

The possibility of pathogenic specialization in $O$. yallundae and $O$. acuformis is a question that has not been studied in depth. Old studies on this subject were all published before the identification of the two Oculimacula species and host-specific pathogenicity was often analyzed in relation to different species at the same time as in relation to different cultivars. Evaluation of response specificity demands tests of several genotypes with several isolates, and assessments of the statistical interaction between isolates and genotypes while avoiding the confounding direct and interacting effects of environment. Scott and Hollins (1977) reported such a study and concluded that genotype $\mathrm{x}$ isolate $\mathrm{x}$ environment was much larger than genotype $\mathrm{x}$ isolate interaction, which means that differential responses of cultivars to isolates were not repeatable over experiments.

Resistant wheat cultivars derived from the French cultivar 'Cappelle-Desprez' dominated European wheat markets for two decades from 1953 (Hollins et al. 1988). Their resistance remained effective during prolonged and widespread use and can be recorded as durable (Gale et al. 1984; Law et al. 1988; Johnson 1992a).

Few and contradictory results were reported regarding durability of resistance conferred by Pchl: increases in yield loss of 'Madsen' relative to susceptible cultivars were observed over a 12-year period in eyespot field evaluation tests in the Pacific Northwest, where two cultivars carrying Pchl, 'Madsen' and 'Hyak', were grown over 500,000 ha (Jones et al. 1995) whereas no isolate of the pathogen obtained from France was found virulent on Pchl-carrying genotypes (Saur and Cavelier 1995; J. Jahier, personal communication) but Pchl-carrying cultivars were not widely grown in France until recently.

Differential response to the two Oculimacula species is a related subject more often discussed in recent publications. Poupard et al. (1994) showed that cultivars with Pchl ('Roazon' and 'Rendezvous') carried much less $O$. acuformis material as measured by ELISA, than $O$. yallundae material, in the same experimental field and the same environmental conditions where plants had 


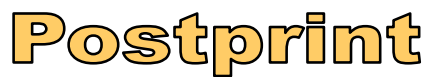

Version définitive du manuscrit publié dans / Final version of the manuscript published in :

Journal of Phytopathology, 2011, 159 (7-8), 457-470 $\quad$ http://dx.doi.org/10.1111/j.1439-0434.2011.01795.x been inoculated separately with isolates of the two species. In this experiment, susceptible and moderately resistant cultivars had similar ELISA values with the two species. On the contrary, Pch1 was found to be highly effective against both species whereas Pch2 was significantly less effective against $O$. yallundae than $O$. acuformis (Burt et al. 2010). While studying the eyespot resistance found in D. villosum Uslu et al. (1998) observed that resistance to the two pathogen species could be conferred by different genes. Similarly, Sheng and Murray (2009) observed that $20 \%$ of the Ae. longissima lines they tested responded differently to the two species and Burt et al. (2010) identified four T. monococcum lines that responded differently to the two species.

Pathogenic specialization seems to exist in interactions between Oculimacula and wheat relatives. In T. tauschii, a differential response was repeatedly observed with two lines and several isolates in three European laboratories (Scott et al. 1976). Similarly, a differential response was observed in triticale (X Tricosecale) when challenged with O. acuformis isolates (M. Trottet, personal communication).

\section{Problems and future prospects}

Quite a few problems and significant new perspectives on eyespot of wheat have been provided by the research findings over many years. The fact that eyespot can be caused by two different species, O. yallundae and O. acuformis (Lucas et al. 2000; Crous et al. 2003) and that both have the ability to adapt to selection pressures (King and Griffin 1985; Murray 1996; Leroux and Gredt 1997) has important implications for disease management. Disease monitoring, chemical control and plant breeding will depend on a clear understanding of pathogenic specialization, genetics and population biology of the pathogen species (Dyer and Lucas 1995; Dyer et al. 2000; Bateman and Jenkyn 2001).

Alternative cultural practices, such as cultivar mixtures, induced resistance and biocontrol, deserve further research in regard eyespot management. Mixtures of resistant and susceptible cultivars seem to be able to reduce lodging significantly under severe eyespot attacks, even if symptoms are not reduced (Mundt 2002). This effect is likely due to resistant cultivars physically supporting susceptible cultivars. The endophyte Piriformospora indica, a Basidiomycota originating from the Thar desert of Rajasthan, India, was shown to colonize wheat roots and to have a significant reducing effect on eyespot symptoms (Serfling et al. 2007). It is not clear whether this effect is a result of host defense induction (systemic acquired resistance or priming) or an increased plant growth rate that helps the host to produce a leaf sheath faster than the pathogen goes through them. However, $P$. indica was apparently not able to restrict leaf pathogens in the field, raising doubts about its applicability for wheat production. Finally, the resistance inducer Benzo $(1,2,3)$ thiadiazole-7-carbothioic acid S-methylester (BTH) had no effect against eyespot disease in a field 457-470. DOI : 10.1111/j.1439-0434.2011.01795.x 


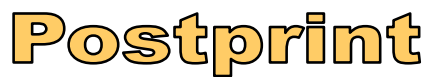

Version définitive du manuscrit publié dans / Final version of the manuscript published in :

Journal of Phytopathology, 2011, 159 (7-8), 457-470 http://dx.doi.org/10.1111/j.1439-0434.2011.01795.x experiment which aimed primarily to evaluate its effects on foliar diseases and grain yield of winter wheat (Stadnik and Buchenauer 1999).

Molecular genetic studies of the eyespot pathogens are practicable and could be applied to identify factors determining fungicide resistance, pathogenicity and host specificity, to understand pathogen reproduction, and to reveal the mechanism of the infection process. Such studies could ultimately enable the design of novel chemical compounds to interfere with key steps in the infection processes or spore production and hence prevent pathogen dispersal. However, very few results in these research areas were published in the last 10 years and genomic studies do not seem to be underway for the eyespot pathogens.

Field evaluations and seedling tests in greenhouses or growth chambers based on visual scores are time- and resource-consuming, labor intensive, and sometimes inaccurate, because the pathogen grows slowly in planta and damage to plants is difficult to assess because it is not restricted to the plant surface. Additionally, the test requires substantial replication to obtain reliable results, owing to a significant degree of non-genetic interference and is seldom effective when applied to single plant selection (Koebner and Summers 2003). Moreover, young plant and adult plant responses to eyespot are only partially correlated. Finally, field tests are quite slow, taking up to 11 months. As a consequence, if phenotypic tests are useful to discover and map resistance genes, breeders need genetic markers for these resistance genes in order to manipulate them efficiently in breeding.

The introgressed segment surrounding Pchl in VPM-1 seems to have unfavourable effects for optimal yield. A yield penalty is associated with Pchl in the absence of the pathogen (Worland et al. 1988). Substitution of chromosome 7D of VPM-1 into several adapted UK wheat varieties depressed yield by about 6\% (Law et al. 1988). Yield potential of VPM-1 was 30\% lower than the long-term check 'Nugains' on the basis of 16 site-years of tests in Washington State (Jones et al. 1995). VPM-1 and some of its derivatives possess a large segment of chromosome from the $D^{V}$ genome of Ae. ventricosa, and yield-depressing genes are probably carried together with eyespot resistance on this segment. Chao et al. (1989) considered that the $7 \mathrm{D}^{\mathrm{v}}$ segment in VPM-1 represented most of the 7D chromosome because VPM-1 was different from the reference Ae. ventricosa accession they used at only one RFLP locus (Xpsr129) and one isozyme locus (alpha-Amy-D2), whereas it had the Ae. ventricosa allele at 12 RFLP loci, including the most distal at both ends of the chromosome and the most proximal ones near the centromere, and at three other loci (Pch1, Ep-D1, and Rc3). Similarly, according to C-banding analysis, chromosome 7D appeared entirely substituted by chromosome $7 \mathrm{D}^{\mathrm{V}}$ in four VPM lines (Badaeva et al. 2008). Quite long ago it was shown that the deleterious linkages between low yield and Pchlcan be broken (Worland and Law 1986; Law et al. 1988). More recently, molecular results showed that some cultivars carrying Pch1, like for example 'Coda', have a much shorter 7D ${ }^{\mathrm{v}}$ segment than VPM-1 (Leonard et al. 2008). 


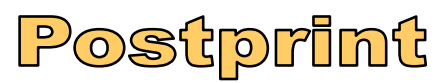

Version définitive du manuscrit publié dans / Final version of the manuscript published in :

Journal of Phytopathology, 2011, 159 (7-8), 457-470 http://dx.doi.org/10.1111/j.1439-0434.2011.01795.x

The codominant endopeptidase marker Ep-DI was long considered useful to monitor the introgression of Pch1 from VPM-1 to elite lines. However, the endopeptidase test is destructive for single seed and generally not sufficiently accurate when applied on an embryo-less half-grain basis. It is therefore usually applied as a bulked progeny test, delaying selection by one generation (Koebner and Summers 2003). An improved method of assaying for the Ep-DIb marker using roots from a single seedling was shown to be accurate in predicting resistance (Santra et al. 2006). This isoelectric focusing assay is not highly robust; it is a technically demanding procedure and produces toxic chemical compounds, and it is often difficult to distinguish the $E p-D 1 b$ allele from certain orthologous Ep-Al and Ep-BI alleles (Koebner et al. 1988). A DNA-based marker for the presence of the eyespot resistance gene is thus desirable for routine use in selection programs, because it would provide a simple, rapid and accurate assay for resistance at all stage of plant growth, and could be multiplexed with DNA markers for other traits. Fortunately, several SSR and STS markers have been identified that can be used in this context.

Yield losses due to eyespot can still occur in cultivars with the resistance of 'Cappelle-Desprez' (Hollins et al. 1988). A significant loss in grain yield due to eyespot was observed with VPM-1 once in 4 years under favourable disease conditions (Murray and Bruehl 1986). 'Madsen' sustained significant yield losses (average 15\%) in 5 out 13 tests when inoculated and non-inoculated plots were compared (Jones et al. 1995) and the level of eyespot resistance varied among material with Pchl resistance gene (Lind 1999). On the contrary, additional fungicide treatment for eyespot control was predicted to be no longer routinely required in 'Rendezvous' that combines at least Pch1 and Pch2 (Hollins et al. 1988; Law et al. 1988; Burt et al. 2010). Similarly, Doussinault and Douaire (1978) observed that $F_{2}$ families obtained by crossing VPM and Cappelle-Desprez were slightly more eyespot resistant than VPM itself at the adult stage and obtained transgressive progenies in the $\mathrm{F}_{4}$ generation. Two lines derived from these crosses showed significantly higher resistance than VPM-1 a few years later (Doussinault et al. 1983b). Allan and Roberts (1991) also identified transgressive progenies for eyespot resistance in a cross between VPM-1/Moisson 951 (resistant with Pchl) and 'Cerco', with resistance at the level of 'Cappelle-Desprez'. Through the use of SSR or STS markers flanking Pch2 in combination with Pch1-linked loci like Xorw1, Xorw5 and Xorw6, marker assisted selection of genotypes carrying Pchl and Pch2 could be successful and much easier than with phenotypic screens. This should provide farmers with cultivars having adequate eyespot resistance in the majority of the years.

It has often been suggested that the combination of Pchl and the resistance of 'Cappelle-Desprez' should also sustain Pchl durability, largely because of 'Cappelle-Desprez' resistance durability. Whether the combination of Pch1 and Pch2 will be durable remains an unanswered question, and for this reason, further sources of resistance should be identified at the genetic level. 457-470. DOI : 10.1111/j.1439-0434.2011.01795.x 


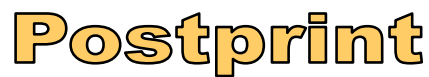

Version définitive du manuscrit publié dans / Final version of the manuscript published in :

Journal of Phytopathology, 2011, 159 (7-8), 457-470 $\quad$ http://dx.doi.org/10.1111/j.1439-0434.2011.01795.x

Eyespot resistance is generally not complete and environmental effects on its expression can be large. For these reasons, potentially valuable genotypes can be lost if breeders are not able to identify resistant genotypes. For example, Pch3 was mapped with an assay performed with the GUS-transformed strain, and this would not have been possible with visual disease ratings (Jones et al. 1995).

In the event of Pchl resistance breakdown, new sources of eyespot resistance genes will be needed (Thiele et al. 2002) together with suitable genetic markers. Cultivars with improved eyespot resistance will then be produced through introgression of the new genes into new cultivars or through pyramiding of several resistance genes. This probably will be possible only with closely linked molecular markers for the various eyespot resistance genes. Various accessions of T. tauschii, T. monococcum, T. durum, T. dicoccoides and T. turgidum were identified in the 1990s as potential sources of eyespot resistance, but transfer of these putatively new source genes into hexaploid wheat, identification and mapping of the major genes represents a huge amount of work that is still incomplete. Association mapping with DArT (Semagn et al. 2006; Crossa et al. 2007), SNP markers when available in sufficient density, or other marker techniques could help in localizing genes of interest on the basis of currently available phenotypic results and identified markers could help in incorporating, pyramiding and stacking of resistance genes in commercial wheat cultivars. Wheat is well served in development of genomic tools, which offer the promise of improved genetic control of eyespot as well as a broader genetic base to exploit in variety improvement.

\section{Acknowledgements}

This work was supported by grants from the Knowledge Innovation Program of the Chinese Academy of Sciences (KSCX1-YW0-3 and KSCX2-YW-N-052). We thank David C. Lees, INRA Orléans, for his critical reading of the manuscript. We thank the reviewers for their careful reading which helped us improve this article.

\section{References}

Albertini C, Gredt M, Leroux P. (1999) Mutations of the $\beta$-tubulin gene associated with different phenotypes of benzimidazole resistance in the cereal eyespot fungi Tapesia yallundae and Tapesia acuformis. Pestic Biochem Physiol 64:17-31.

Albertini C, Gredt M, Leroux P. (2003) Polymorphism of 14 $\alpha$-demethylase gene (I) in the cereal eyespot fungi Tapesia acuformis and Tapesia yallundae. Eur J Plant Pathol 109:117-128.

Allan RE, Morris CF, Line RF, Anderson JA, Walker-Simmons MK, Donaldson E. (2000) Registration of 'Coda' club wheat. Crop Sci 40:578-579.

Allan RE, Peterson CJ, Jr., Rubenthaler GL, Line RF, Roberts DE. (1989) Registration of 'Madsen' 


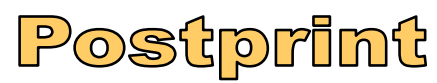

Version définitive du manuscrit publié dans / Final version of the manuscript published in :

Journal of Phytopathology, 2011, 159 (7-8), 457-470

http://dx.doi.org/10.1111/j.1439-0434.2011.01795.x wheat. Crop Sci 29:1575-1576.

Allan RE, Peterson CJ, Jr., Rubenthaler GL, Line RF, Roberts DE. (1990) Registration of 'Hyak' wheat. Crop Sci 30:234.

Allan RE, Roberts DE. (1991) Inheritance of reaction to strawbreaker foot rot in two wheat populations. Crop Sci 31:943-947.

Allan RE, Rubenthaler GL, Morris CF, Line RF. (1993) Registration of three soft white winter wheat germplasm lines resistant or tolerant to strawbreaker foot rot. Crop Sci 33:1111-1112.

Assefa S, Fehrmann H. (1998) Resistance in Aegilops species against leaf rust, stem rust, Septoria tritici blotch, eyespot and powdery mildew of wheat. Z Pflanzenkr Pflanzenschutz 105:624-631.

Badaeva ED, Dedkova OS, Koenig J, Bernard S, Bernard M. (2008) Analysis of introgression of Aegilops ventricosa Tausch genetic material in a common wheat background using C-banding. Theor Appl Genet 117:803-811.

Bang R. (1986) Experimentelle Untersuchungen zur genetischen Analyse und zur Verbesserung der Widerstandsfähigkeit des Saatweizens Triticum aestivum L. gegenüber Pseudocercosporella herpotrichoides (Fron) Deighton. Univ. of Halle-Wittenberg, Germany, PhD Thesis.

Bateman G, Jenkyn J. (2001) Biology and control of stem-base diseases of cereals in UK. Pesticide Outlook 12:103-106.

Bateman GL, Edwards SG, Marshall J, Morgan LW, Nicholson P, Nuttall M, Parry DW, Schrancher M, Turner AS. (2000) Effects of cultivar and fungicides on stem-base pathogens, determined by quantitative PCR, and on diseases and yield of wheat. Ann Appl Biol 137:213-221.

Blakemore EJA, Dobson MJ, Hocart MJ, Lucas JA, Peberdy JF. (1989) Transformation of Pseudocercosporella herpotrichoides using two heterologous genes. Curr Genet 16:177-180.

Boerner A, Freytag U, Sperling U. (2006) Analysis of wheat disease resistance data originating from screenings of Gatersleben genebank accessions during 1933 and 1992. Genet Resour Crop Evol 53:453-465.

Borum F. (2001) Danish wheat pool. In: The world wheat book. A history of wheat breeding. Bonjean AP, Angus WJ (eds) Londres - Paris - New York, Editions TEC \& DOC, pp 243-256.

Bowyer P, Mueller E, Lucas J. (2000) Use of an isocitrate lyase promoter-GFP fusion to monitor carbon metabolism of the plant pathogen Tapesia yallundae during infection of wheat. Mol Plant Pathol 1:253-262.

Bruehl GW, Nelson WL. (1964) Techniques for mass inoculations of winter wheat in the field with Cercosporella herpotrichoides. Plant Dis Rep 48:863-865.

Bunkers GJ. (1991) Expression of the Escherichia coli $\beta$-glucuronidase gene in Pseudocercosporella herpotrichoides. Appl Environ Microbiol 57:2896-2900.

Burt C, Hollins TW, Powell N, Nicholson P. (2010) Differential seedling resistance to the eyespot 


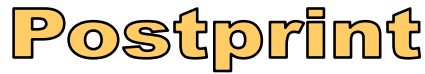

Version définitive du manuscrit publié dans / Final version of the manuscript published in :

Journal of Phytopathology, 2011, 159 (7-8), 457-470 http://dx.doi.org/10.1111/j.1439-0434.2011.01795.x pathogens, Oculimacula yallundae and Oculimacula acuformis, conferred by Pch2 in wheat and among accessions of Triticum monococcum. Plant Pathol 59:819-828.

Cadle MM, Murray TD, Jones SS. (1997) Identification of resistance to Pseudocercosporella herpotrichoides in Triticum monococcum. Plant Dis 81:1181-1186.

Cadle MM, Murray TD, Jones SS. (1998) Mapping of resistance to Pseudocercosporella herpotrichoides in Triticum tauschii. Phytopathology 88:S106.

Campbell KAG, Allan RE, Anderson J, Pritchett JA, Little LM, Morris CF, Line RF, Chen X, Walker-Simmons MK, Carter BP, Burns JW, Jones SS, Reisenauer PE. (2005) Registration of 'Chukar' wheat. Crop Sci 45:1657-1659.

Chao S, Sharp PJ, Worland AJ, Warham EJ, Koebner RMD, Gale MD. (1989) RFLP-based genetic maps of wheat homoeologous group 7 chromosomes. Theor Appl Genet 78:495-504.

Chapman N, Burt C, Dong H, Nicholson P. (2008) The development of PCR-based markers for the selection of eyespot resistance genes Pch1 and Pch2. Theor Appl Genet 117:425-433.

Chapman NH, Burt C, Nicholson P. (2009) The identification of candidate genes associated with Pch2 eyespot resistance in wheat using cDNA-AFLP. Theor Appl Genet 118:1045-1057.

Cox CM, Murray TD, Jones SS. (2002) Perennial wheat germ plasm lines resistant to eyespot, cephalosporium stripe, and wheat streak mosaic. Plant Dis 86:1043-1048.

Crossa J, Burgueno J, Dreisigacker S, Vargas M, Herrera-Foessel SA, Lillemo M, Singh RP, Trethowan R, Warburton M, Franco J, Reynolds M, Crouch JH, Ortiz R. (2007) Association analysis of historical bread wheat germplasm using additive genetic covariance of relatives and population structure. Genetics 177:1889-1913.

Crous PW, Groenewald JZ, Gams W. (2003) Eyespot of cereals revisited : ITS phylogeny reveals new species relationships. Eur J Plant Pathol 109:841-850.

de la Peña RC, Murray TD. (1994) Identifying wheat genotypes resistant to eyespot disease with a $\beta$-glucuronidase-transformed strain of Pseudocercosporella herpotrichoides. Phytopathology 84:972-977.

de la Peña RC, Murray TD, Jones SS. (1996) Linkage relations among eyespot resistance gene Pch2, endopeptidase Ep-A1b, and RFLP marker Xpsr121 on chromosome 7A of wheat. Plant Breed 115:273-275.

de la Peña RC, Murray TD, Jones SS. (1997) Identification of an RFLP interval containing Pch2 on chromosome 7AL in wheat. Genome 40:249-252.

Delibes A, Doussinault G, Mena M, Lopez-Braña I, Garcia-Olmedo F. (1988) Eyespot resistance gene Pch-1 from Aegilops ventricosa is associated with a different chromosome in wheat line H-93-70 than the resistance factor in "Roazon" wheat. Theor Appl Genet 76:573-576.

Delibes A, Garcia-Olmedo F. (1973) Biochemical evidence of gene transfer from the MV genome 


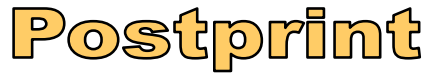

Version définitive du manuscrit publié dans / Final version of the manuscript published in :

Journal of Phytopathology, 2011, 159 (7-8), 457-470 $\quad$ http://dx.doi.org/10.1111/j.1439-0434.2011.01795.x of Aegilops ventricosa to hexaploid wheat. In: Sears ER, Sears LMS (eds) Proc 4th Int Wheat Genet Symp. Mo Agric Exp Stn. Columbia Mo, pp 161-167.

Douhan GW, Murray TD, Dyer PS. (2002a) Species and mating-type distribution of Tapesia yallundae and T. acuformis and occurrence of apothecia in the US Pacific Northwest. Phytopathology 92:703-709.

Douhan GW, Murray TD, Dyer PS. (2003) Population genetic structure of Tapesia acuformis in Washington State. Phytopathology 93:650-656.

Douhan GW, Peever TL, Murray TD. (2002b) Multilocus population structure of Tapesia yallundae in Washington State. Mol Ecol 11:2229-2239.

Doussinault G. (1973) Comportement de douze variétés de Blé tendre vis-à-vis du Piétin-verse (Cercosporella herpotrichoides Fron). Conséquences pour la sélection. Ann Amélior Plantes 23:333-346.

Doussinault G, Delibes A, Sanchez-Monge R, Garcia-Olmedo F. (1983a) Transfer of a dominant gene for resistance to eyespot disease from a wild grass to hexaploid wheat. Nature 303:698-700.

Doussinault G, Dosba F, Jahier J. (1983b) New results on the improvement of the level of resistance to eyespot in wheat. In: Sakamoto S (ed) Proc 6th Int Wheat Genet Symp. Kyoto, Japan, pp 193-198.

Doussinault G, Dosba F, Jahier J. (1988) Use of a hybrid between Triticum aestivum L. and Aegilops ventricosa Tausch in wheat breeding. In: Miller TE, Koebner RMD (eds) Proc 7th Int Wheat Genet Symp. Cambridge, England, pp 253-258.

Doussinault G, Douaire G. (1978) Analyse d'un croisement diallèle chez le blé tendre pour l'étude de la résistance au piétin-verse (Cercosporella herpotrichoides Fron). Ann Amélior Plantes 28:479-491.

Doussinault G, Koller J, Touvin H, Dosba F. (1974) Utilisation des géniteurs VPM1 dans l'amélioration de l'état sanitaire du blé tendre. Ann Amélior Plantes 24:215-241.

Dyer PS, Bradshaw RE. (2002) First report of apothecia of Tapesia yallundae occurring on the wild grass Holcus lanatus (Yorkshire Fog) in New Zealand. Plant Pathol 51:806-806.

Dyer PS, Furneaux PA, Douhan G, Murray TD. (2001) A multiplex PCR test for determination of mating type applied to the plant pathogens Tapesia yallundae and Tapesia acuformis. Fungal Genet Biol 33:173-180.

Dyer PS, Hansen J, Delaney A, Lucas JA. (2000) Genetic control of resistance to the sterol $14 \alpha$-demethylase inhibitor fungicide prochloraz in the cereal eyespot pathogen Tapesia yallundae. Appl Environ Microbiol 66:4599-4604.

Dyer PS, Lucas JA. (1995) Incidence of apothecia of Tapesia yallundae at set-aside sites in England and sensitivity of the ascospore offspring to the fungicides benomyl and prochloraz. Plant Pathol 


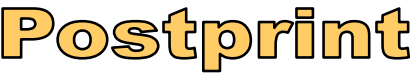

Version définitive du manuscrit publié dans / Final version of the manuscript published in :

Journal of Phytopathology, 2011, 159 (7-8), 457-470 $\quad$ http://dx.doi.org/10.1111/j.1439-0434.2011.01795.x 44:796-804.

Dyer PS, Nicholson P, Rezanoor HN, Lucas JA, Peberdy JF. (1993) Two-allele heterothallism in Tapesia yallundae, the teleomorph of the cereal eyespot pathogen Pseudocercosporella herpotrichoides. Physiol Mol Plant Pathol 43:403-414

Eckert M, Maguire K, Urban M, Foster S, Fitt B, Lucas J, Hammond-Kosack K. (2005) Agrobacterium tumefaciens-mediated transformation of Leptosphaeria spp. and Oculimacula spp. with the reef coral gene DsRed and the jellyfish gene gfp. FEMS Microbiol Lett 253:67-74.

Figliuolo G, Jones SS, Murray TD, Zeuli PLS. (1998) Characterization of tetraploid wheat germplasm for resistance to Pseudocercosporella herpotrichoides, cause of eyespot disease. Genet Resour Crop Evol 45:47-56.

Fitt BDL, Goulds A. (1988) Eyespot (Pseudocercosporella herpotrichoides) epidemiology in relation to prediction of disease severity and yield loss in winter wheat - a review. Plant Pathol 37:311-328.

Fitt BDL, Goulds A, Hollins TW, Jones DR. (1990) Strategies for control of eyespot (Pseudocercosporella herpotrichoides) in UK winter wheat and winter barley. Ann Appl Biol 117:473-486.

Fitt BDL, Huang YJ, van den Bosch F, West JS. (2006) Coexistence of related pathogen species on arable crops in space and time. Annu Rev Phytopathol 44:163-182.

Frei U, Wenzel G. (1993) Differentiation and diagnosis of Pseudocercosporella herpotrichoides (Fron) Deighton with genomic DNA probes. J Phytopathol 139:229-237.

Gac ML, Montfort F, Cavelier N, Hourmant P. (1999) Value of the polymerase chain reaction for studying the development in the field of Tapesia yallundae and Tapesia acuformis and for evaluating effects of a triticonazole seed treatment. J Phytopathol 147:707-715.

Gac ML, Montfort F, Cavelier N, Sailland A. (1996) Comparative study of morphological, cultural and molecular markers for the characterization of Pseudocercosporella herpotrichoides isolates. Eur J Plant Pathol 102:325-337.

Gale MD, Scott PR, Law CN, Ainsworth CC, Hollins TW, Worland AJ. (1984) An $\alpha$-amylase gene from Aegilops ventricosa transferred to bread wheat together with a factor for eyespot resistance. Heredity 52:431-435.

Griffey CA, Das MK, Baldwin RE, Waldenmaier CM. (1994) Yield loss in winter barley resulting from a new race of Puccinia hordei in North America. Plant Dis 78:256-260.

Hollins TW, Lockley KD, Blackman JA, Scott PR, Bingham J. (1988) Field performance of Rendezvous, a wheat cultivar with resistance to eyespot (Pseudocercosporella herpotrichoides) derived from Aegilops ventricosa. Plant Pathol 37:251-260.

Huguet-Robert V, Dedryver F, Röder MS, Korzun V, Abélard P, Tanguy AM, Jaudeau B, Jahier J. 


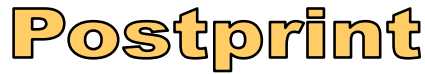

Version définitive du manuscrit publié dans / Final version of the manuscript published in :

Journal of Phytopathology, 2011, 159 (7-8), 457-470 http://dx.doi.org/10.1111/j.1439-0434.2011.01795.x (2001) Isolation of a chromosomally engineered durum wheat line carrying the Aegilops ventricosa Pch1 gene for resistance to eyespot. Genome 44:345-349.

Johnson R. (1992a) Past, present and future apportunities in breeding for disease resistance, with examples from wheat. Euphytica 63:3-22.

Johnson R. (1992b) Reflections of a plant pathologist on breeding for disease resistance, with emphasis on yellow rust and eyespot of wheat. Plant Pathol 41:239-254.

Jones SS, Donaldson E, Lyon SR, Morris CF, Hoffman R. (2000) Registration of 'Edwin' wheat. Crop Sci 40:1198.

Jones SS, Murray TD, Allan RE. (1995) Use of alien genes for the development of disease resistance in wheat. Annu Rev Phytopathol 33:429-443.

Julian AM, Lucas JA. (1990) Isozyme polymorphism in pathotypes of Pseudocercosporella herpotrichoides and related species from cereals. Plant Pathol 39:178-190.

King JE. (1977) Surveys of diseases of winter wheat in England and Wales, 1970-75. Plant Pathol 26:8-20.

King JE, Griffin MJ. (1985) Survey of benomyl resistance in Pseudocercosporella herpotrichoides on winter wheat and barley in England and Wales in 1983. Plant Pathol 34:272-283.

Koebner RMD, Martin PK. (1990) Association of eyespot resistance in wheat cv. 'Cappelle-Desprez' with endopeptidase profile. Plant Breed 104:312-317.

Koebner RMD, Miller TE, Snape JW, Law CN. (1988) Wheat endopeptidase : genetic control, polymorphism, intrachromosomal gene location, and alien variation. Genome 30:186-192.

Koebner RMD, Summers RW. (2003) 21st century wheat breeding: plot selection or plate detection? Trends Biotechnol 21:59-63.

Kronstad WE, Rohde CR, Kolding MF, Metzger RJ. (1978) Registration of 'Stephens' Wheat. Crop Sci 18:1097-1097.

Kwasna H, Bateman GL, Ward E. (2010) Microbiota in wheat roots evaluated by cloning of ITS1/2 rDNA and sequencing. J Phytopathol 158:278-287.

Law CN, Scott PR, Worland AJ, Hollins TW. (1975) The inheritance of resistance to eyespot (Cercosporella herpotrichoides) in wheat. Genet Res 25:73-79.

Law CN, Worland AJ, Hollins TW, Koebner RMD, Scott PR. (1988) The genetics of two sources of resistance to eyespot (Pseudocercosporella herpotrichoides) in wheat. In: Miller TE, Koebner RMD (eds) Proc 7th Int Wheat Genet Symp. Cambridge, England, pp 835-840.

Leonard J, Watson C, Carter A, Hansen J, Zemetra R, Santra D, Campbell K, Riera-Lizarazu O. (2008) Identification of a candidate gene for the wheat endopeptidase Ep-D1 locus and two other STS markers linked to the eyespot resistance gene Pch1. Theor Appl Genet 116:261-270.

Leroux P, Gredt M. (1997) Evolution of fungicide resistance in the cereal eyespot fungi Tapesia 
Version définitive du manuscrit publié dans / Final version of the manuscript published in :

Journal of Phytopathology, 2011, 159 (7-8), 457-470 $\quad$ http://dx.doi.org/10.1111/j.1439-0434.2011.01795.x yalundae and Tapesia acuformis in France. Pestic Sci 51:321-327.

Li HJ, Arterburn A, Jones SS, Murray TD. (2004) A new source of resistance to Tapesia yallundae associated with a homoeologous group 4 chromosome in Thinopyrum ponticum. Phytopathology 94:932-937.

Li HJ, Arterburn M, Jones SS, Murray TD. (2005) Resistance to eyespot of wheat, caused by Tapesia yallundae, derived from Thinopyrum intermedium homoeologous group 4 chromosome. Theor Appl Genet 111:932-940.

Li HJ, Conner RL, Murray TD. (2008) Resistance to soil-borne diseases of wheat: Contributions from the wheatgrasses Thinopyrum intermedium and Th ponticum. Can J Plant Sci 88:195-205.

Liatukas Z, Ruzgas V. (2008) Resistance of Lithuanian winter wheat breeding material to eyespot. Zemdirbyste-Agriculture 95:336-343.

Lind V. (1992) Measuring the severity of eyespot disease induced by Pseudocercosporella herpotrichoides (Fron) Deighton in wheat cultivars at different growth stages. Plant Breed 108:202-209.

Lind V. (1999) Variation of resistance to Pseudocercosporella herpotrichoides (Fron) Deighton in wheat genotypes carrying the gene Pch-1. Plant Breed 118:281-287.

Lind V. (2000) Analysis of diallel crosses between wheat genotypes with genetically different resistance to Pseudocercosporella herpotrichoides (Fron) Deighton. Plant Breed 119:449-453.

Lind V, Zuchner S, Spanakakis A, Thiele A. (1994) Analyses of interations of wheat cultivars in tests for resistance to Pseudocercosporella herpotrichoides. Plant Breed 113:272-280.

Lucas JA. (2004) Survival, surfaces and susceptibility - the sensory biology of pathogens. Plant Pathol 53:679-691.

Lucas JA, Dyer PS, Murray TD. (2000) Pathogenicity, host-specificity, and population biology of Tapesia spp., causal agents of eyespot disease of cereals. Adv Bot Res 33:225-258.

Ma Z, Michailides TJ. (2005) Advances in understanding molecular mechanisms of fungicide resistance and molecular detection of resistant genotypes in phytopathogenic fungi. Crop Prot 24:853-863.

Macer RCF. (1966) Resistance to eyespot disease (Cercosporella herpotrichoides) determined by a seedling test in some forms of Triticum, Aegilops, Secale, Hordeum. J Agric Sci 67:389-397.

Maia N. (1967) Obtention de blés tendres résistants au piétin-verse (Cercosporella herpotrichoides) par croisements interspécifiques. C R Acad Agric Fr 53:149-154.

Marshall D, Sutton RL. (1995) Epidemiology of stripe rust, virulence of Puccinia striiformis f. Sp. hordei, and yield loss in barley. Plant Dis 79:732-737.

Matusinsky P, Mikolasova R, Klem K, Spitzer T. (2009) Eyespot infection risks on wheat with respect to climatic conditions and soil management. J Plant Pathol 91:93-101. 


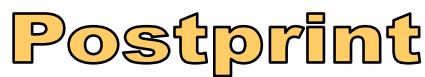

Version définitive du manuscrit publié dans / Final version of the manuscript published in :

Journal of Phytopathology, 2011, 159 (7-8), 457-470 http://dx.doi.org/10.1111/j.1439-0434.2011.01795.x

Matusinsky P, Mikolasova R, Klem K, Spitzer T, Urban T. (2008a) The role of organic vs. conventional farming practice, soil management and preceding crop on the incidence of stem-base pathogens on wheat. J Plant Dis Protect 115:17-22.

Matusinsky P, Mikolasova R, Spitzer T, Klem K. (2008b) Colonization of winter wheat stem bases by communities of pathogenic fungi. Cereal Res Commun 36:77-88.

McMillin DE, Allan RE, Roberts DE. (1986) Association of an isoenzyme locus and straw breaker foot rot resistance derived from Aegilops ventricosa in wheat. Theor Appl Genet 72:743-747.

Mena M, Doussinault G, Lopez-Braña I, Aguaded S, Garcia-Olmedo F, Delibes A. (1992) Eyespot resistance gene Pch-1 in H-93 wheat lines. Evidence of linkage to markers of chromosome group 7 and resolution from the endopeptidase locus Ep-D1b. Theor Appl Genet 83:1044-1047.

Meyer N, Karlovsky P, Zahn M, Lind V, Krämer I, Ordon F. (2006) Quantifizierung des Befalls von Oculimacula acuformis und O. yallundae als Grundlage zur Entwicklung molekularer Marker für Resistenzgene gegenüber der Halmbruchkrankheit bei Triticum aestivum. In: Bericht über die 57. Tagung 2006 der Vereinigung der Pflanzenzüchter und Saatgutkaufleute Österreichs. Gumpenstein, pp 112.

Meyer N, Lind V, Heindorf M, Korzun V, Friedt W, Ordon F. (2010) Diagnostic value of molecular markers linked to the eyespot resistance gene Pchl in wheat. Euphytica 177:267-275.

Meyer N, Lind V, Zahn M, Friedt W, Ordon F. (2008) Entwicklung molekularer Marker für Resistenzgene gegen Oculimacula spp., die Erreger der Halmbruchkrankheit im Weizen (Triticum aestivum). In: Abwehrstrategien gegen biotische Schaderreger Zuchtung von Hackfruchten und Sonderkulturen. Tagungsband der 59. Jahrestagung der Vereinigung der Pflanzenzuchter und Saatgutkaufleute Osterreichs. Raumberg-Gumpenstein, Austria, pp 35-38.

Mueller E, Bailey A, Corran A, Michael AJ, Bowyer P. (2001) Ornithine decarboxylase knockout in Tapesia yallundae abolishes infection plaque formation in vitro but does not reduce virulence toward wheat. Mol Plant-Microbe Interact 14:1303-1311.

Mundt CC. (2002) Performance of wheat cultivars and cultivar mixtures in the presence of Cephalosporium stripe. Crop Prot 21:93-99.

Muranty H, Jahier J, Tanguy AM, Worland AJ, Law C. (2002) Inheritance of resistance of wheat to eyespot at the adult stage. Plant Breed 121:536-538.

Murray TD. (1996) Resistance to benzimidazole fungicides in the cereal eyespot pathogen, Pseudocercosporella herpotrichoides, in the Pacific Northwest 1984 to 1990. Plant Dis 80:19-23.

Murray TD, Bruehl GW. (1983) Role of the hypodermis and secondary cell wall thickening in basal stem internodes in resistance to strawbreaker foot rot in winter wheat. Phytopathology 73:261-268. Murray TD, Bruehl GW. (1986) Effects of host resistance to Pseudocercosporella herpotrichoides and foot rot severity on yield and yield components in winter wheat. Plant Dis 70:851-856. 457-470. DOI : 10.1111/j.1439-0434.2011.01795.x 


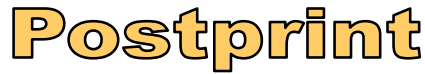

Version définitive du manuscrit publié dans / Final version of the manuscript published in :

Journal of Phytopathology, 2011, 159 (7-8), 457-470 http://dx.doi.org/10.1111/j.1439-0434.2011.01795.x

Murray TD, de la Peña RC, Yildirim A, Jones SS. (1994) A new source of resistance to Pseudocercosporella herpotrichoides, cause of eyespot disease of wheat, located on chromosome 4V of Dasypyrum villosum. Plant Breed 113:281-286.

Murray TD, Ye HZ. (1986) Papilla formation and hypersensitivity at penetration sites and resistance to Pseudocercosporella herpotrichoides in winter wheat. Phytopathology 76:737-744.

Nicholson P, Hollins TW, Rezanoor HN, Anamthawatjonsson K. (1991) A comparison of cultural, morphological and DNA markers for the classification of Pseudocercosporella herpotrichoides. Plant Pathol 40:584-594.

Nicholson P, Rezanoor HN. (1994) The use of random amplified polymorphic DNA to identify pathotype and detect variation in Pseudocercosporella herpotrichoides. Mycol Res 98:13-21.

Nicholson P, Rezanoor HN, Hollins TW. (1993) Classification of a worldwide collection of isolates of Pseudocercosporella herpotrichoides by RFLP analysis of mitochondrial and ribosomal DNA and host range. Plant Pathol 42:58-66.

Nicholson P, Rezanoor HN, Hollins TW. (1994) The identification of a pathotype-specific DNA probe for the R-type of Pseudocercosporella herpotrichoides. Plant Pathol 43:694-700.

Nicholson P, Rezanoor HN, Simpson DR, Joyce D. (1997) Differentiation and quantification of the cereal eyespot fungi Tapesia yallundae and Tapesia acuformis using a PCR assay. Plant Pathol $46: 842-856$.

Nicholson P, Turner AS, Edwards SG, Bateman GL, Morgan LW, Parry DW, Marshall J, Nuttall M. (2002) Development of stem-base pathogens on different cultivars of winter wheat determined by quantitative PCR. Eur J Plant Pathol 108:163-177.

Papaikonomou M, Lucas JA. (1994) RAPD analysis of 515 eyespot isolates from field sites in Europe. In: Brighton Crop Protection Conference - Pests and Diseases. pp 481-486.

Peterson CJ, Jr., Vogel OA, Bruehl GW, Allan RE. (1974) Registration of Cerco Cercosporella foot rot resistant wheat germplasm. Crop Sci 14:612.

Poupard P, Frei U, Cavalier N, Lind V. (1995) Genetic diversity in W-type and R-type populations of Pseudocercosporella herpotrichoides based on DNA restriction fragment length polymorphisms. J Phytopathol 143:99-104.

Poupard P, Grare S, Cavelier N, Lind V. (1994) Development of Pseudocercosporella herpotrichoides (Fron) Deighton var. herpotrichoides and var. acuformis on wheat plants measured by ELISA. J Phytopathol 140:301-311.

Poupard P, Simonet P, Cavelier N, Bardin R. (1993) Molecular characterization of Pseudocercosporella herpotrichoides isolates by amplification of ribosomal DNA internal transcribed spacers. Plant Pathol 42:873-881.

Priestley RA, Dewey FM, Nicholson P, Rezanoor HN. (1992) Comparison of isoenzyme and DNA 457-470. DOI : 10.1111/j.1439-0434.2011.01795.x 


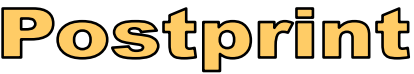

Version définitive du manuscrit publié dans / Final version of the manuscript published in :

Journal of Phytopathology, 2011, 159 (7-8), 457-470 $\quad$ http://dx.doi.org/10.1111/j.1439-0434.2011.01795.x markers for differentiating W-pathotype, R-pathotype and C-pathotype of Pseudocercosporella herpotrichoides. Plant Pathol 41:591-599.

Ray RV, Crook MJ, Jenkinson P, Edwards SG. (2006) Effect of eyespot caused by Oculimacula yallundae and $O$. acuformis, assessed visually and by competitive PCR, on stem strength associated with lodging resistance and yield of winter wheat. J Exp Bot 57:2249-2257.

Ray RV, Jenkinson P, Edwards SG. (2004) Effects of fungicides on eyespot, caused predominantly by Oculimacula acuformis, and yield of early-drilled winter wheat. Crop Prot 23:1199-1207.

Roberts DE, Allan RE. (1990) Natural and mass selection for improving strawbreaker foot rot resistance in winter wheat. Crop Sci 30:510-515.

Santra DK, Watt C, Little L, Kidwell KK, Campbell KG. (2006) Comparison of a modified assay method for the endopeptidase marker Ep-Dlb with the Sequence Tag Site marker XustSSR2001-7DL for strawbreaker foot rot resistance in wheat. Plant Breed 125:13-18.

Saur L, Cavelier N. (1995) Caractéristiques d'isolats de Pseudocercosporella herpotrichoides provenant de variétés de blé posédant le gène de résistance Pch1. Z Pflanzenkr Pflanzenschutz 102:472-477.

Scott PR, Defosse L, Vandam J, Doussinault G. (1976) Infection of lines of Triticum, Secale, Aegilops and Hordeum by isolates of Cercosporella herpotrichoides. Trans Br mycol Soc $66: 205-210$.

Scott PR, Hollins TW. (1977) Interactions between cultivars of wheat and isolates of Cercosporella herpotrichoides. Trans Br mycol Soc 69:397-403.

Semagn K, Bjørnstad Å, Skinnes H, Maroy AG, Tarkegne Y, William M. (2006) Distribution of DArT, AFLP, and SSR markers in a genetic linkage map of a doubled-haploid hexaploid wheat population. Genome 49:545-555.

Serfling A, Wirsel SGR, Lind V, Deising HB. (2007) Performance of the biological control fungus Piriformospora indica on wheat under greenhouse and field conditions. Phytopathology 97:523-531.

Sheng H, Murray TD. (2009) Identifying resistance genes for eyespot of wheat in Aegilops longissima. Phytopathology 99:S119-S119.

Simonet M. (1957) Hybrides interspécifiques et intergénériques. Ann Amélior Plantes 4:395-411.

Singh G, Dyer PS, Ashby AM. (1999) Intra-specific and inter-specific conservation of mating-type genes from the discomycete plant-pathogenic fungi Pyrenopeziza brassicae and Tapesia yallundae. Curr Genet 36:290-300.

Sprague R. (1936) Relative susceptibility of certain species of Gramineae to Cercosporella herpotrichoides. J Agric Res 53:659-670.

Stadnik MJ, Buchenauer H. (1999) Control of wheat diseases by a benzothiadiazole-derivative and 


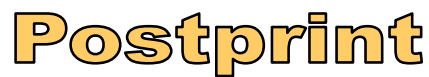

Version définitive du manuscrit publié dans / Final version of the manuscript published in :

Journal of Phytopathology, 2011, 159 (7-8), 457-470 $\quad$ http://dx.doi.org/10.1111/j.1439-0434.2011.01795.x modern fungicides. Z Pflanzenkr Pflanzenschutz 106:466-475.

Stewart EL, Liu ZW, Crous PW, Szabo LJ. (1999) Phylogenetic relationships among some cercosporoid anamorphs of Mycosphaerella based on rDNA sequence analysis. Mycol Res 103:1491-1499.

Strausbaugh CA, Murray TD. (1989) Inheritance of resistance to Pseudocercosporella hepotrichoides in three cultivars of winter wheat. Phytopathology 79:1048-1053.

Summers RW, Koebner RMD, Hollins TW, Förster J, Macartney DP. (1988) The use of an isozyme marker in breeding wheat (Triticum aestivumi) resistant to the eyespot pathogen (Pseudocercosporella herpotrichoides). In: Miller TE, Koebner RMD (eds) Proc 7th Int Wheat Genet Symp. Cambridge, England, pp 1195-1197.

Takeuchi T, Kuninaga S. (1996) Determination of relationships in Pseudocercosporella herpotrichoides by analysis of mitochondrial DNA. Mycol Res 100:693-701.

Thiele A, Schumann E, Peil A, Weber WE. (2002) Eyespot resistance in wheat x Aegilops kotschyi backcross lines. Plant Breed 121:29-35.

Thomas D, Maraite H, Boutry M. (1992) Identification of rye-type and wheat-type of Pseudocercosporella herpotrichoides with DNA probes. Journal of General Microbiology 138:2305-2309.

Turner AS, Nicholson P, Edwards SG, Bateman GL, Morgan LW, Todd AD, Parry DW, Marshall J, Nuttall M. (2001) Evaluation of diagnostic and quantitative PCR for the identification and severity assessment of eyespot and sharp eyespot in winter wheat. Plant Pathol 50:463-469.

Uslu E, Miller TE, Rezanoor NH, Nicholson P. (1998) Resistance of Dasypyrum villosum to the cereal eyespot pathogens, Tapesia yallundae and Tapesia acuformis. Euphytica 103:203-209.

Vahl U, Müller G. (1991) Endopeptidase EP-1 as a marker for the eyespot resistance gene Pch1 from Aegilops ventricosa in wheat line 'H-93-70'. Plant Breed 107:77-79.

Vahl U, Müller G, Thiele A, Thiele M. (1987) Multiple endipeptidases as biochemical marker for resistance of winter wheat to Pseudocercosporella herpotrichoides (Fron) Deighton. Plant Breed 99:218-225.

Vanova M, Polisenska I, Vejl P, Skupinova S. (2000) Differentiation of cereal eyespot fungi using morphologic characteristics and PCR diagnostic tests. Plant Prot Sci 36:57-64.

Vincent A, Ponchet J, Koller J. (1952) Recherche de variétés de blés tendres peu sensibles au piétin-verse : résultats préliminaires. Ann Amélior Plantes 3:459-472.

Wallwork H. (1987) A Tapesia teleomorph for Pseudocercosporella herpotrichoides, the cause of eyespot of wheat. Australas Plant Pathol 16:92-93.

Walsh K, Korimbocus J, Boonham N, Jennings P, Hims M. (2005) Using real-time PCR to discriminate and quantify the closely related wheat pathogens Oculimacula yallundae and 


\section{Pos\{}

Version définitive du manuscrit publié dans / Final version of the manuscript published in :

Journal of Phytopathology, 2011, 159 (7-8), 457-470 $\quad$ http://dx.doi.org/10.1111/j.1439-0434.2011.01795.x

Oculimacula acuformis. J Phytopathol 153:715-721.

Wood HM, Dickinson MJ, Lucas JA, Dyer PS. (2001) Cloning of the CYP51 gene from the eyespot pathogen Tapesia yallundae indicates that resistance to the DMI fungicide prochloraz is not related to sequence changes in the gene encoding the target site enzyme. FEMS Microbiol Lett 196:183-187.

Worland AJ, Law CN. (1986) Resistance to eyespot. Annual report of the Plant Breeding Institute, 1985.:62-63.

Worland AJ, Law CN, Hollins TW, Koebner RMD, Giura A. (1988) Location of a gene for resistance to eyespot (Pseudocercosporella herpotrichoides) on chromosome 7D of bread wheat. Plant Breed 101:43-51.

Yildirim A, Jones SS, Murray TD. (1998) Mapping a gene conferring resistance to Pseudocercosporella herpotrichoides on chromosome $4 \mathrm{~V}$ of Dasypyrum villosum in a wheat background. Genome 41:1-6.

Yildirim A, Jones SS, Murray TD, Cox TS, Line RF. (1995) Resistance to stripe rust and eyespot diseases of wheat in Triticum tauschii. Plant Dis 79:1230-1236.

Yildirim A, Jones SS, Murray TD, Line RF. (2000) Evaluation of Dasypyrum villosum populations for resistance to cereal eyespot and stripe rust pathogens. Plant Dis 84:40-44. 
Version définitive du manuscrit publié dans / Final version of the manuscript published in :

Journal of Phytopathology, 2011, 159 (7-8), 457-470

http://dx.doi.org/10.1111/j.1439-0434.2011.01795.x

Table 1. Resistant germplasm containing Pch1

\begin{tabular}{|c|c|c|}
\hline Name of line & $\begin{array}{c}\text { Registration } \\
\text { year }\end{array}$ & Pedigree \\
\hline Alcazar $^{\mathrm{a}}$ & 2004 & \\
\hline Allister ${ }^{\mathrm{a}}$ & 2003 & \\
\hline Andante $^{\mathrm{b}}$ & 1992 & Moulin/D-172-6-4 \\
\hline Arbon $^{\mathrm{a}}$ & 1990 & Maris-Huntsman/US-363 \\
\hline Astuce $^{\mathrm{a}}$ & 2004 & \\
\hline Attlass $^{\mathrm{a}}$ & 2005 & \\
\hline Audace $^{a}$ & 1995 & $(\mathrm{VM} 1347 \times$ XM480.18) x VM480.4 \\
\hline Azimut $^{\mathrm{a}}$ & 2004 & \\
\hline Balthazar $^{\mathrm{a}}$ & 1995 & Faucon/Rendezvous \\
\hline Beamer $^{c}$ & & \\
\hline Bill $^{\mathrm{d}}$ & 1998 & \\
\hline Brandt $^{\mathrm{e}}$ & & \\
\hline $\mathrm{Cara}^{\mathrm{f}}$ & 2006 & WA7752 // WA6581 / WA7217 \\
\hline $\operatorname{Cardos}^{\mathrm{a}, \mathrm{g}}$ & 2000 & Cappelle-Desprez//Taras/Hadmerslebener-230-60 \\
\hline Certo $^{\mathrm{h}, \mathrm{g}}$ & & \\
\hline Cetus $^{\mathrm{g}, \mathrm{i}}$ & 2005 & \\
\hline Chukar ${ }^{\mathrm{j}, \mathrm{k}}$ & 2003 & WA7665/Rulo \\
\hline $\operatorname{Coda}^{\mathrm{j}, \mathrm{I}}$ & & Tres//Madsen/Tres \\
\hline Eclipse $^{\mathrm{a}}$ & 1999 & \\
\hline $\mathrm{Ecu}^{\mathrm{a}}$ & 1988 & L-1035/L-1474//Moisson \\
\hline Farandole $^{\mathrm{a}}$ & 1999 & VM713/CF1851//CF1616/Renan \\
\hline Finch $^{\mathrm{j}}$ & 2003 & Dusty//Wa7164/Dusty \\
\hline Flèchedor $^{\mathrm{a}}$ & 1992 & $\begin{array}{l}\text { VPM/Moisson//US-60-43/3/Prieur-61/4/Fidel } \\
\text { VPM/Moisson//US-60-43/3/Prieur/4/Fidel }\end{array}$ \\
\hline Format $^{\mathrm{g}}$ & 2007 & \\
\hline FR-50 & & VPM-1/McCall \\
\hline Grisby $^{\mathrm{a}}$ & 2002 & Wild emmer /Obelisk/Taurus \\
\hline Hermann $^{\mathrm{g}, \mathrm{m}}$ & 2004 & \\
\hline Hyak $^{\mathrm{n}}$ & 1989 & VPM-1/Moisson 421//2*Tyee \\
\hline Hybnos- $1^{\text {h }}$ & 1999 & \\
\hline Intense $^{a}$ & 2001 & \\
\hline Kris $^{\mathrm{d}}$ & 1997 & \\
\hline Leiffer $^{\mathrm{d}, \mathrm{g}}$ & 2004 & \\
\hline Limes $^{g}$ & 2002 & \\
\hline Lone $^{\mathrm{e}}$ & 1992 & \\
\hline $\operatorname{Lynx}^{\mathrm{e}}$ & 1992 & Sleipner/Rendezvous \\
\hline Madsen $^{n}$ & 1988 & VPM-1/Moisson 951/2*Hill 81 \\
\hline Manager $^{\mathrm{g}}$ & 2006 & \\
\hline Mitchel $^{\mathrm{a}}$ & 2001 & \\
\hline Mobil $^{\mathrm{O}}$ & 1991 & Kronjuwel/Roazon \\
\hline Mohler ${ }^{c}$ & & \\
\hline Oratorio $^{\mathrm{a}}$ & 1995 & H-84290/Genial \\
\hline Osmin ${ }^{\mathrm{h}}$ & 2004 & \\
\hline Pactole $^{\mathrm{a}}$ & 1986 & Top/VPM-71 \\
\hline Piko $^{\text {g,h }}$ & 1994 & CWW-3319.5/3/Kraka//Maris-Huntsman/Fruhgold \\
\hline PR22R28 ${ }^{\mathrm{a}}$ & 2001 & \\
\hline Ralf $^{\mathrm{a}}$ & 1997 & Cario/Tadorna//Ibis/Ferto/3/Burma/4/Rendezvous \\
\hline $\mathrm{RE} 8714^{\mathrm{a}}$ & & $\begin{array}{l}\text { (Aegilops squarrosa } \mathrm{n}^{\circ} 33 / T \text {. dicoccum } \mathrm{n}^{\circ} 119 \text { ) // (VPM/Moisson) / } \\
\text { Beauchamp }\end{array}$ \\
\hline RE9001 $^{\mathrm{a}}$ & & (80MH3/R3.7)//(R3.7/74RHD8.4) \\
\hline Regain $^{\mathrm{a}}$ & 1995 & R-3-7/Bounty//Adam/3/R-3-7/Bounty//Darius \\
\hline $\operatorname{Renan}^{\mathrm{a}}$ & 1989 & (Mironovskaia X Maris Huntsman) X [(VPM X Moisson) X Courtot] \\
\hline Rendezvous $^{\mathrm{a}}$ & & (VPM x Hobbit) x Virtue \\
\hline Ressor $^{\mathrm{a}}$ & 2004 & RE9001/82RmultiHD10 \\
\hline Roazon $^{\mathrm{a}}$ & 1978 & VPM-1-1-1-2-R-4/Moisson \\
\hline
\end{tabular}




\section{Pos\{}

Version définitive du manuscrit publié dans / Final version of the manuscript published in :

Journal of Phytopathology, 2011, 159 (7-8), 457-470 $\quad$ http://dx.doi.org/10.1111/j.1439-0434.2011.01795.x

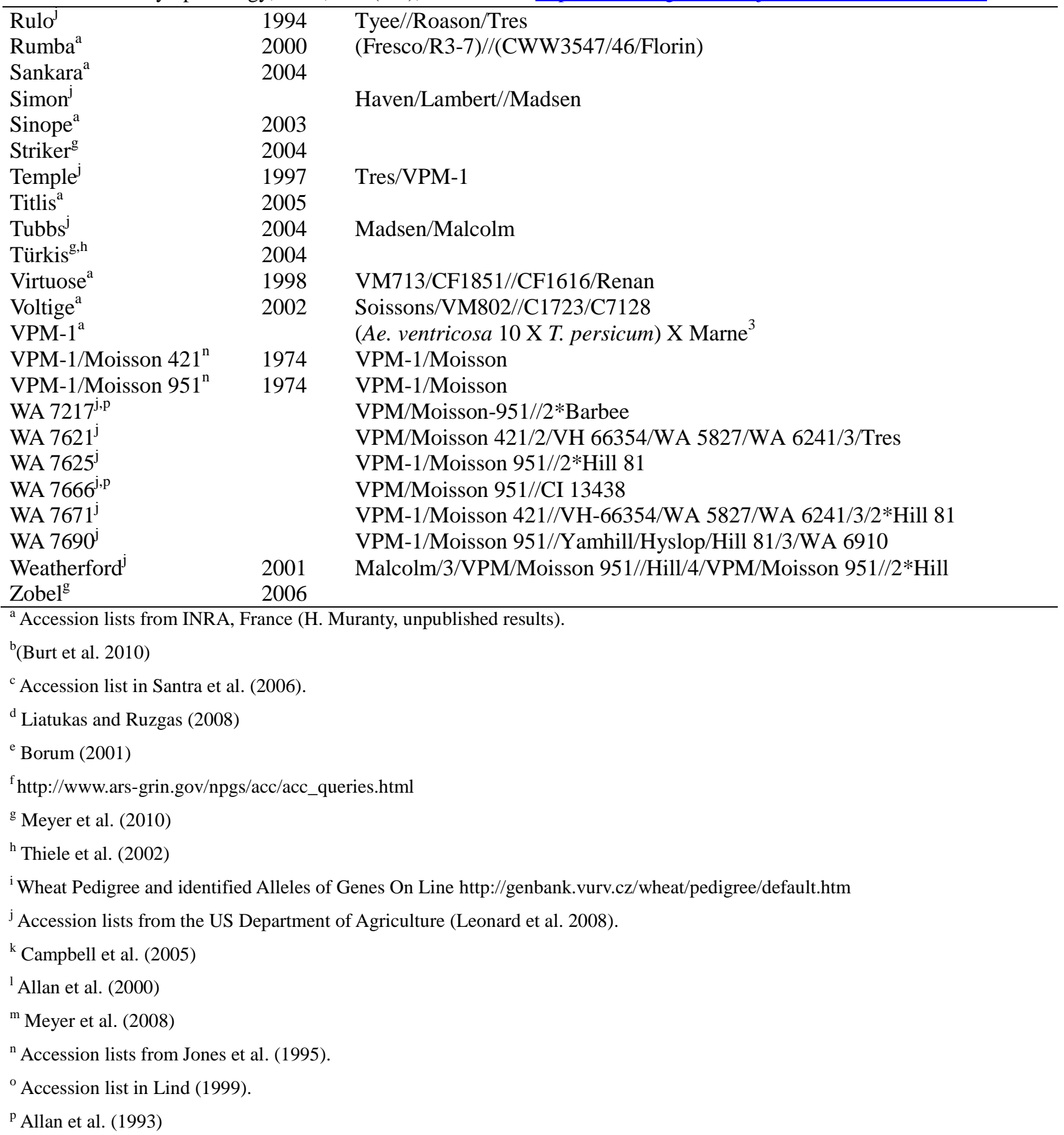


Version définitive du manuscrit publié dans / Final version of the manuscript published in :

Journal of Phytopathology, 2011, 159 (7-8), 457-470 http://dx.doi.org/10.1111/j.1439-0434.2011.01795.x

Table 2. Genes for resistance to eyespot mapped using genetic markers

\begin{tabular}{|c|c|c|c|c|c|}
\hline $\begin{array}{l}\text { Linked } \\
\text { genes }\end{array}$ & Marker name & $\begin{array}{l}\text { Marker } \\
\text { type }\end{array}$ & Marker interval & Population structure & References \\
\hline \multirow[t]{25}{*}{ Pchl } & $E p-D b 1$ & isozyme & Tight linkage & $\begin{array}{l}30 \mathrm{~F}_{5} \text { lines 'VPM/Moisson } \\
421 \text { '//'Selection } 101 \text { ' } \\
689 \text { resistant lines }\end{array}$ & $\begin{array}{l}\text { McMillin et al. (1986) } \\
\text { Summers et al. (1988) }\end{array}$ \\
\hline & Xpsr121 & RFLP & Tight linkage & 68 RSL HS(VPM7D)/HS & Chao et al. (1989) \\
\hline & Xust2001-7DL & SSR & $3 \mathrm{cM}$ away from $P c h 1$ & 38 breeding lines & Santra et al. (2006) \\
\hline & XW7Dest & SSR & $6 \mathrm{cM}$ away from $P c h 1$ & \multirow[t]{3}{*}{$90 \mathrm{BC}_{5}$ lines $\mathrm{HS}(\mathrm{VPM} 7 \mathrm{D}) / \mathrm{HS}$} & \multirow[t]{3}{*}{ Chapman et al. (2008) } \\
\hline & $X g w m 428$ & SSR & $8 \mathrm{cM}$ away from $X w m c 14$ & & \\
\hline & $X B-g l u 7 D$ & EST & Tight linkage & & \\
\hline & Xwmc273 & SSR & \multirow{4}{*}{$\begin{array}{l}\text { Loose linkage (between } 9.4 \\
\text { and } 7 \mathrm{cM} \text { from } P c h l \text { ) }\end{array}$} & \multirow{7}{*}{$\begin{array}{l}254 \mathrm{RIL}_{6} \text { (Coda×Brundage), } \\
\text { germplasm survey of } 44 \text { lines } \\
94 \text { RILs of ITMI population } \\
\text { (W7984×Opata85) }\end{array}$} & \multirow{7}{*}{$\begin{array}{l}\text { Leonard et al. (2008) } \\
\text { Chapman et al. (2008) }\end{array}$} \\
\hline & Xcfa2040 & SSR & & & \\
\hline & Xwmc634 & SSR & & & \\
\hline & Xgwm37 & SSR & & & \\
\hline & Xwmc14 & SSR & \multirow[t]{3}{*}{ Tight linkage } & & \\
\hline & Xbarc97 & SSR & & & \\
\hline & $X c f d 175$ & SSR & & & \\
\hline & Xorw5 & STS & \multirow[t]{3}{*}{ Tight linkage } & \multirow{3}{*}{$\begin{array}{l}254 \mathrm{RIL}_{6} \text { (Coda×Brundage), } \\
\text { germplasm survey of } 44 \text { lines; } \\
23 \mathrm{DH} \text { lines '293' (Pchl) x 'St906' } \\
\text { (susceptible), } 24 \text { DH lines '359' } \\
\text { (Pchl) x 'St906' (susceptible) and } \\
80 \mathrm{DH} \text { lines 'Chevalier' } \\
\text { (susceptible) x WW3640 (Pchl) }\end{array}$} & \multirow[t]{3}{*}{ Leonard et al. (2008) } \\
\hline & Xorw1 & STS & & & \\
\hline & Xorw6 & STS & & & \\
\hline & K110 & AFLP & Loose linkage (2.1 and 4.3 & \multirow{9}{*}{$\begin{array}{l}\text { DH populations segregating for } \\
\text { Pch }\end{array}$} & \multirow{9}{*}{ Meyer et al. (2008) } \\
\hline & SSR03 & SSR & cM from $P$ chl) & & \\
\hline & $K 210$ & AFLP & Tight linkage & & \\
\hline & Xust2001-7DL & SSR & & & \\
\hline & SSR01 & SSR & & & \\
\hline & SSRO2 & SSR & & & \\
\hline & SSR08 & SSR & & & \\
\hline & Xorw6 & STS & & & \\
\hline & Xorw5 & STS & & & \\
\hline \multirow[t]{8}{*}{ Pch2 } & $E p-A 1 b$ & isozyme & $15 \%$ recombined with $P c h 2$ & \multirow[t]{2}{*}{$80 \mathrm{RSL}$ CS(CD7A)/CS } & \multirow[t]{2}{*}{ de la Peña et al. (1996) } \\
\hline & Xpsr121 & RFLP & $\begin{array}{l}3.8 \% \text { recombined with } \\
E p-A 1 b\end{array}$ & & \\
\hline & Xcdo347 & RFLP & $11 \mathrm{cM}$ distal to $P c h 2$ & \multirow[t]{2}{*}{102 RSL CS(CD7A $) / C S$} & \multirow[t]{2}{*}{ de la Peña et al. (1997) } \\
\hline & Xwg380 & RFLP & $18.8 \mathrm{cM}$ proximal to $P \operatorname{ch} 2$ & & \\
\hline & Xwmc525 & SSR & $X w m c 525$ Linked with $P c h 2$ & \multirow[t]{3}{*}{$192 \mathrm{~F}_{2} \mathrm{CS}(\mathrm{CD} 7 \mathrm{~A}) / \mathrm{CS}$} & \multirow[t]{3}{*}{ Chapman et al. (2008) } \\
\hline & Xwmc346 & SSR & in $7 \mathrm{cM}$ interval, flanked by & & \\
\hline & Xcfa2040 & SSR & $X w m c 346$ and $X c f a 2040$ & & \\
\hline & 5 fragments & AFLP & unknown & $\begin{array}{l}\text { DH population segregating for } \\
\text { Pch2 }\end{array}$ & Meyer et al. (2008) \\
\hline \multirow[t]{2}{*}{$\operatorname{Pch} 3$} & Xcdo949 & RFLP & The two markers bracket the & 82 F2 (Yangmai-5(4V(4D)) ×a & \multirow[t]{2}{*}{ Yildirim et al. (1998) } \\
\hline & Xbcd588 & RFLP & Pch3 in a $33 \mathrm{cM}$ interval & disomic addition line $(\mathrm{CS}+4 \mathrm{~V})$ & \\
\hline
\end{tabular}

RSL, single chromosome recombinant lines; RIL, recombinant inbred lines; DH, double haploid; RFLP, restriction fragment length polymorphisms; SSR, simple sequence repeat; STS, sequence-tagged site. 